\title{
HOW HOUSING BRANDS USE SOCIAL MEDIA IN THEIR MARKETING COMMUNICATIONS?: A CONTENT ANALYSIS
}

\author{
Meltem ÖZTÜRK ${ }^{1} \&$ T. Perçin BATUM ${ }^{2}$
}

\begin{abstract}
In recent years, there is an increase in the creativeness and innovativeness levels of the pioneer and attractive real estate investments. It is an advantage for housing brands to attain brand loyalty. One of the best ways to convey the loyalty is to establish and manage a brand image through social media by using the tools on time and effectively. In this study, social media usage (as amarketing communications - MARCOMtool) of big-scale housing brands which are top ranked in Turkey and classified by a number of criteria and their positions in social media have been examined through content analysis. The study shows that the top companies follow similar ways (for example, mostly seen as introducing new projects for sales, introducing ads and promotions, etc.) and they need expertise for a differentiated and effective social media management. Within this scope, the study makes some suggestions to housing brands in the light of these findings.
\end{abstract}

Key Words: Housing Brands, Social Media, Marketing Communications, Content Analysis

Jel Codes: M31, M39

Başvuru: 30.07.2018 Kabul: 26.12.2018

\section{KONUT MARKALARI PAZARLAMA İLETISSIMİNDE SOSYAL MEDYAYI NASIL KULLANIYOR?: BİR İÇERIK ANALIZİ}

$\ddot{O} \mathbf{z}$

Son yıllarda gayrimenkul markalaşmasında öncü ve çekici gayrimenkul yatırımlarının yenilikçiliği ve yaratıcılı̆̆ında bir artış yaşanmaktadır. Gayrimenkul markasının, marka sadakatine sahip olması önemli bir avantajdır. Bunu aktarmanın en iyi yollarından birisi de günümüz koşullarında sosyal medya araçlarını zamanında ve etkin kullanarak bir marka imajını oluşturmak ve yönetmektir. Bu çalışmada Türkiye'de ilk siralarda yer alan ve çeşitli özelliklere göre sinuflandirllan büyük konut markalarının pazarlama iletişimi araçlarından sosyal medyayı kullanımı, sosyal medya kullanımı (pazarlama iletişimi olarak- MARCOMtool gibi) içerik analizi yöntemiyle incelenmektedir. Araştırma sonucunda, ilk stralarda yer alan konut markalarının benzer kriterleri (örneğin en çok satışlar için yeni projeleri anlatma, reklam ve promosyonlar tanitma gibi) kullandiğ l, farklılaşma konusunda etkin pazarlama temelli sosyal medya uzmanlı̆̆ına ihtiyaç duydukları görülmüştür. Ayrıca, bulgular ışı̆̆ı̆nda konut markalarına çeşitli önerilerde bulunulmaktadır.

\footnotetext{
1 Dr. Öğr. Gör., Pamukkale Üniversitesi, Honaz MYO, Pazarlama ve Reklamcıllk Bölümü, mozturk@pau.edu.tr (correspondence author), https://orcid.org/0000-0002-4299-3819

2 Arş.Gör.,Anadolu Üniversitesi, İİBF, İşletme Bölümü, tpbatum@gmail.com,

https://orcid.org/0000-0003-0912-7772
} 
Anahtar Kelimeler: Konut Markaları, Sosyal Medya, Pazarlama İletişimi, İçerik Analizi

Jel Kodları: M31, M39

\section{INTRODUCTION}

Although branding is important both in terms of enabling a product or a company to raise its perceived value in the market and to position it in an anticipated way, it also depends on certain conditions and criteria. Branding can be the result of the evaluationofall corporate strategies as a whole in the organization. The preference for the companies operating in the real estate sector differing from their competitors depends on whether they can gain the trust of the consumers, they can create corporate brand imageand they can carry brand values. Therefore, branding processes must be planned and managed very seriously. Especially due to increasing competition among the housing brands, branding studies has gained importance. On account of the need for trust and quality, the necessity of positioning housing brands increases as the consumers turn to well-known companies and demand. Because, a brand needs to reassure itself with its distinguishing characteristics from other companies offering similar products in the competitive markets. This trust component ensures differentiation by positioning the brand.

A brand management strategy which is conducted by defining a specific consumer group of products in the housing branding, and that depends on the characteristics of the target audience's lifestyle, psychological and other consumer behaviors, will increase the competitiveness. At this point, the success of healthy and sustainable marketing communication activities (promotion) that will create a brand perception will ensure that the housing brands are preferred.

Today, consumers regard a house to be bought as a living space as well as an investment. Factors that are effective in this preference are; the change in the income level of the individuals, the rising trend in the country's economy, credit facilities, and housing alternatives in different dimensions offered by real estate projects. An important part of the housing production is realized by the private sector. Luxury housing projects for the upper income group and projects for the middle and lower income groups, many of which are undertaken by TOKI (Housing Development Administration of Turkey), are emerging as the main source of revival in the housing market. As can be understood from the large projects realized by the branded housing sector over the last five years, concentration of real estate brands especially on housing has affected individual consumers' preferences. At this point, companies that place their brand in mind of the consumers need to maintain strong marketing communication activities. In this digital age that allows fast sharing of information and other subjects, the main issue is to access the customer directly. This can be further individualized through social media toolsand platforms.

The way to succeed in marketing of real estate projects requires creativity, strategy development and financial responsibility. Creativity and the possibilities are important factorsin designing houses, making environmental planning, determining resources and 
messages to be conveyed. The success of a creative work is only possible with an effective branding and marketing communication strategy aiming to the right consumer at the right time (IF Marketing \& Advertising,2012).

The marketing strategies and evaluations to be established in the housing marketing are determined within the 4Ps (product, price, promotion and place) of effective marketing. In terms of services, it will also be necessary to set a strategy according to 7Ps of marketing factors (In addition to 4Ps, people, process, and physical evidence). For the real estate sector: (1) Product; what is sold (real estate, service, idea or person); (2) Price; commission or price list for real estate services; (3) Place; where and when the service or real estate is offered for real estate consumers. Newspapers, radio, TV, magazines, web sites, apartment tax, public houses, mails, newsletters, telephone-address books, advertising boards, automobile signposts, company cards, letterhead paper and fax cover pages. (4) Promotion; the design of advertising, propaganda, public relations and sales, and many other ways to inform and convince real estate consumers about products and services, according to company goals and target audience (Barrell and Nash, 2005).

Considering the products and services offered in the housing sector, location, people, and processes in 7P should also be taken into account. The factors of 7P stand out in the marketing of services. Effective marketing strategies to be developed in the housing sector should also be determined on 7P. This is because the presentation of services is important in the differentiation of the housing product and as well as the contribution of the project manufacturer firm to this product. Location is effective in terms of the country, city, region and/or neighborhood of the housing product concerned; people, especially sales representatives who are active in the marketing of housing products, in terms of their characteristics and contributions; processes are effective in terms of the services, qualifications and presentation style and timing of housing products.

If a more detailed description is to be made, the people factor of $7 \mathrm{P}$ is the employees of an organization that communicate face to face with the customer in the presentation of the products / services of the company. The performance of an employee who is well trained and who knows the firm and its services will explain the performance of the firm. The concept of location, as physical evidence, is the environment in which the customers and firm interact in delivering products and / or services. It is a communication tool in the procurement by the consumer of the services offered by the firm. The environment and its features where services are provided (security, lightning, healthcare services, cultural and environmental features) are the principal factors in the presentation of housing products. The process describes the order of services and presentation methods that create the value position that the firm commits to the consumers. Well-designed processes are the methods that ensure that the committed values of the customer are delivered in the desired quality, time and suitability and provide the consumer with the guarantee (Kushwaha and Agrawal, 2015; Anitsal, Girard and Anitsal, 2012).

\subsection{Promotion/Marketing Communication in Housing Branding}

Marketing communication activity is the most important phase of the communication 
process that will allow the marketing plan to reach the consumer. Marketers now conduct their marketing communication studies in the form of integrated marketing communication using a wide variety of tools. The important issue here is to carry out promotional activities, television, advertisement, direct electronic mail, personal sales, public relations, brochures, magazine magazines and internet media in a coordinated and integrated manner that may enable accurate and timely access to the target audience within the framework of efficiency and profitability to be expected from the market. Today, the concept of promotion is used equivalent to the marketing communication, which is a broader expression.

The American Marketing Association defines integrated marketing communication as a planning process designed to ensure that all brand contacts which an existing or potential customer is exposed to regarding a product, service, or organization arerelated to the intended buyer and consistent over time (marketingpower.com).

In many studies, it is stated that firms are basically able to use five marketing communication tools (promotion)classified as -advertising, public relations, personal sales, direct marketing, sales promotion- (Cherunilam, 2008; Mucuk, 2012; Kotler and Armstrong, 2010; Fill and McKee, 2011). In addition to the tools mentioned, there are sources where sponsorships and trade fairs are defined as distinct marketing communication tools (De Pelsmacker et al., 2007; Masterman, 2007; Percy, 2008; Smith and Zook, 2011). However, in above classification, sponsorship activities are regarded as a sub-category of public relations, while commercial fairs are defined as a sub-category of personal sales. In this context, marketing communication tools have been evaluated under five main headings.

A variety of tools used in the communication of housing marketing including advertisements (newspapers, television, radio, online internet sites), billboards, sample flats shown at the project site, mail sent to potential buyers, electronic mailing to potential buyers or hand brochures, newsletters of the developers or agencies, joint announcements within the framework of agreements made with various real estate sales sites, public relations, sales made 24/7 from the call center, arrangement / display a model of the housing project, customer visit or propaganda (personal sale) of the agency communicating with potential buyers, packages offering promotions (offers providing other benefits for housing buyers for sales promotion), lobbying activities, and direct sales to land or condominium owners. In the promotion of a real estate, the marketing efforts to attract real estate (public housing, gardens, gardens, floors, commercial and industrial properties, rental housing, etc.) should be planned and implemented taking into account the time and market structure. Today, the most important tool is the sale, promotion, follow-up and measurement of online sales. Depending on the type of housing and the desired effect, the marketing communication of a housing brand is possible by using various communication methods (advertising, sales promotion, public relations, direct marketing and personal sales) according to the budget plan.

For example, advertising campaign strategies and methods (web sites, call centers, brochures, newspaper-radio-TV, bulletin boards, shopping malls, magazines and sectoral 
publications) followed by promotional efforts and personal sales in promoting the housing brand, (via sales and rental offices, e-real estate pages, corporate online sales page of the builder company, sales by phone) may be effective. In addition to these, it is possible toplan promotional activities by using many methods such as public relations, property ownership sales, event organization, sponsorship (for example on a very popular TV program), customer and sales follow-up, promotion in blogs and social media environments, presentations in games or downloadable phone applications.

It may be possible to gain a perspective with examples of activities done in the name of some marketing communication in the housing sector (such as public relations, sales promotion, advertising). From this point of view, for example, Şehrizar Konakları presented by Gap Construction and Emlak Konut Real Estate Investment Partnership Company a subsidiary of TOKI (Public Housing Administration of Turkey), within the scope of Resource Development Practices has been promoted with the slogan of "excellence is a choice" and the advertisement of "The last apartments are waiting for distinguished owners!". In printed press 6 full page ads are made in a day on a single newspaper (Advertisement on a public auction and bidding for EvoraCadde Project with 4.979 housing by Gap Construction Ege Yap1, Soyak Construction, Agaoglu and Teknik Yap1, Solid Construction (Milliyet Newspaper, 2015). This suggests that the housing sector has been supported by various market dynamics (e.g. urban transformation project) and supply and demand have increased. When examining other examples; the advertisement campaign presented with the title "Investment opportunity of all time!" by Mazhar Alanson carried out with Solid Construction and K Yap1 Real Estate Co., promotes a big project plan in Istanbul; Trendist Ataşehir (Milliyet Newspaper, 2015).

The advertisement for Batı Şehir project offered by EgeYapı Group is also within the scope of Resource Development Application of Emlak Konut Real Estate Investment Partnership Company a subsidiary of TOKI (Public Housing Administration of Turkey), and it is presented by Cem Ceminay with the slogan of local accent"I'll buy my house in Batışehir, and I'll start paying instalments when the house is delivered", and is running a more price based, sincere campaign focused aiming for the middle class (Rates starting from 0,59 and $1 \%$ VAT) with the heading of "Is it you to discover the opportunities in Batışehir?" (konuthaberleri.com, 2015). In addition, the new site project of Dumankaya Construction is presented with full page advertisement. Agaoglu (is a national company in Turkey)on the other hand, is following a more widespread way of responding to the demand of new middle class in a qualified market with the title "Great Agaoglu campaign: $2 \%$ of cash and payment option with no interest and also in all delivery projects and all Agaoglu projects".

The housing product has psychological benefits by nature; the price of the product is higher than the other purchases, the customer needs detailed information, the number of customers is specific and the target audience shows different characteristics in a certain geographical region, sales are not regular and continuous, custom design and production is possible, the ad supports sales: however, it remains weak to provide what the customer wants. Therefore, aneffective integrated marketing communication campaign is required. 
In Mimoza's study (2013), it seems that there are four tools used by construction companies and real estate agencies to respond to the consumer's response. These are: advertising spots, web page of the company, social media such as Facebook and Twitter, outdoor advertising boards of construction companies.

Personal sales, which is the most effective means of promoting communication as it is based on face-to-face communication, is a method used to find potential customers, to inform them about products and services, and to encourage them to buy on their own initiative. Unlike other product types, a housing product has a sales process that depends on the success of the person in charge of direct sales person. Real estate sales require expertise and experience because it is a long-term and family-based decision. Trust (both to the construction company and its sales representatives) and the structure of the human relationships to be established depend on the experience of a salesperson. Also, the salesperson should have the ability and knowledge to reflect the personality and characteristics of the housing brand, be knowledgeable, have ability and experience to establish a corporate business relationship and have expertise in many areas such as credit facilities- interest rates-, additional benefits and / or discounts to be offered to the client, housing valuation knowledge- sales contract- insurance and risk data, housing sales process, branding, etc.

The personal selling activity brings advantage to the housing brands to provide presentations including items in a housing purchase agreement. In other words, this will be achieved through providing processes such as creating a sales proposal, offering and delivering the proposal, temporary collateral (deposit), and dedicated sales by the seller (Geschwender, 2010: 85). The most widespread methods used in real estate sales may be explained as follows (Yuan, 2009: 62): (1) Special agreement, (2) Tender price quotation, (3) Auction.

Publicity made with other means of promotion provides an advantage in sales through personal sales of the housing. However, personal sales are very important for housing brands. Because housing product contains psychological benefits, product price is generally high, customer needs detailed information, number of customers is specific and target audience shows different characteristics in a specific geographical area, sales are not regular and continuous, there is a possibility of special production and design, supports advertisement sales but it is weak enough to provide what the customer requests.

Customer complaints may be encountered in all activities of marketing mix (product type, price, delivery and delivery conditions, after sales services, form of sales agreement, commission fees, and sales time). For this reason, if the housing brands can create an opportunity to provide buyers with the best deal for purchasing their new houses, they will be able to provide main benefit when it comes to attract attention-the key point of interest- and thus create a perceived brand value for the potential buyer. At this point, consistent and continuous attitudes and behaviors of the housing brand and high potential of fulfilling its promise will support the success of retaining the customer.

Housing brands have been able to collect, store, sort and analyze data more effectively 
by using the means provided by the Internet (Weber, 2009: 210). Also, as Reece noted, the customers of the businesses that can use a combination of these tools in the new media will soon complete the buying cycle (awareness - trial - buy - recommend) as a result of brand interaction and experience in digital media (2010: 219). In this context, social media is one of the most important tools of new media in terms of efficiency and frequency of use by the firms. Social media refers to virtual communities created by people with common interests on the Internet, interacting with each other, sharing information, communicating by developing a common understanding, and creating added value, and its activities already constitutes a target audience for intersecting businesses (Fill, 2009: 794).

\subsection{Social Media}

It is difficult to provide a comparative (relative) advantage for product branding in real estate. When developments are sold, it is difficult to maintain branding, depending on the owners and residents who maintain their distinction and image. Since successful branding cannot be built in a night, brand development is more suitable than development projects. Development of a brand and its reflection on consumer's buying behavior is possible with a sustainable brand perception. Creating brand awareness will be possible with the success of the brand communication, that is, when marketing communication activities are carried out within the framework of brand management.

Housing brands have been able to collect, store, sort and analyze data more effectively by using the means provided by the Internet (Weber, 2009: 210). Also, as Reece noted, the customers of the businesses that can use a combination of these tools in the new media will soon complete the buying cycle (awareness - trial - buy - recommend) as a result of brand engagement and experience in digital environments (2010: 219). In this regard, Constantinides and Fountain (2008: 232) classify web 2.0 applications into five main categories within the social media framework. These categories are as follows: 1- Social Networks, 2- Blogs, 3- Collaborative Sites, 4- Forum Announcement Panels, 5- Content Collectors.

Social media refers to virtual communities created by people with common interests on the Internet, interacting with each other, sharing information, communicating by developing a common understanding, and creating added value, and its activities already constitutes a target audience for intersecting businesses (Fill, 2009: 794). These virtual communities often appear on social media platforms where Internet users utilize in order to socialize and share (Scott, 2010: 38). In addition to these interest networks, other social media users also offer great potential for businesses. The web strategies to be implemented in the virtual environment may also serve to support the company and brand identity and to forward the message of the company to the business partners.

Social media emerging as a result of technological development has allowed the individuals to move beyond traditional social sharing with the environment and applications it offers. The term social media means using web based and mobile technologies to establish an interactive dialogue. It includes various forms such as magazines, internet forums, web 
diaries, social blogs, microblogs, wikis, podcasts, photographs or pictures, videos, ratings and social bookmarking (Keskin and Tanyıldız, 2015: 466).

Social media creates a communication environment that is fast, easy, cost-free, dialoguebased and directly accessible to target groups (Boyd and Ellison, 2007: 2). Thanks to social media, it is possible to reach the millions of people at the same time. Due to the fact that it enables instant, rapid and interactive participation of a large number of users, it provides an advantage to the organizations using it in corporate communication activities. Social media provides organizations with interactive user participation, specific usage, measurement, low cost, reaching a wide geographical area, following the target group and getting to know it more closely, introducing the organization and being open to creativity (Vasquez L.M.G and Velez, I. 2011:166). Providing access to such a broad target audience profile at a very low cost is very important in terms of enterprises.

Similar to $4 \mathrm{P}$ which has a marketing mix, social media is defined with $5 \mathrm{C}$. According to this definition, social media consists of conversation, community, commenting, collaboration and contribution (eyeflow.com). In addition, Social Media Tools / Platforms can be summarized as follows (Batum, 2014).

Table 1: Social Media Tools/Platforms

\begin{tabular}{|l|l|}
\hline Social networks & Facebook, MySpace, LinkedIn, Google+, Vkontakt, \\
\hline Blogs & Personal blogs, community blogs, media blogs, corporate blogs \\
\hline Microblogs & Twitter, Friendfeed, Tumblr \\
\hline Wikis & Wikipedia, Google Docs, WetPaint, ekşisözlük \\
\hline Media sharing & YouTube, Pinterest, Slideshare, Flickr, Picasa, Instagram, Dailymotion \\
\hline Virtual worlds & Second Life, FreeRealms, Habbo Hotel, There \\
\hline Social bookmarking & Digg, Reddit, StumbleUpon, delicious \\
\hline Location based SM & Foursquare, Facebook Places, Foodspotting \\
\hline Podcasting & \\
\hline Forums & \\
\hline
\end{tabular}

Source: Batum, 2014.

Social media aims to expand the scope of a product / service delivery by disseminating marketing messages of housing brands and to increase brand awareness, to influence the quality and flow of information, communication efforts resulting in more effective personal messages. It also affects brand loyalty by internalizing the brand image and reputation of the target market. By learning the lifestyle and expectations of the target market and developing suitable housing products and projects, housing brands will be able to realize their marketing objectives effectively. 
Following all these definitions, some results were obtained from the literature studies. Some of them are; evaluating how a social media account of the brand of a company is used in corporate communication- Analyzing the preferences of internet users for social media marketing; - Digital content paid for creating brand awareness by negotiating with experts working in large-scale housing corporations with "Delphi Analysis Technique"; - Determining how companies use data in their strategic decisions, such as social media (such as blogs) under the control of users by collecting data. - Determining how social networks affect purchasing decisions. However, it has been observed that there is no review on housing brands (Bowen and Bowen, 2016, Anjum et al, 2012, Vasquez and Velez, 2011, Smith and Zook, 2011, Çizmeci and Ercan, 2015, Akar, 2010, Onat and Alikılıç, 2008).

\section{METHOD}

In this part of the study, the design of the work, the problems of the work carried out in accordance with the aim, the information about the sampling and analysis process is given.

\subsection{The Aim of the Research}

The most important step in achieving an important place in the consumer mind lies beneath creating a distinguished brand. In the construction sector, urban transformation, reciprocity and 2B laws enacted in 2012- Turkey, create a serious movement especially in the branded housing sector (emlakkulisi.com). In the production of branded housing projects, marketing communication studies should be emphasized in order to show where consumers place their current or new products / services and brands in the market. This is because housing brands that are shaped in accordance with the needs of consumers and their lifestyles and deliver their messages in the right channel and in the correct way will be able to make a difference and will get a continuous share for their brands from the increase in sales volume. For this reason, the method used in the research is the content analysis which is generally used for classification and comparison of data. Content analysis is a method used to characterize and compare documents, interview scrolls, or records. The aim is to define the opinions or documents of the participants systematically (Altunışıket al., 2012: 320).

Nowadays when it is thought that it is the most important channel in terms of the increase in the number of online environments and the effectiveness in reaching the people, transferring the correct marketing communication strategies with correct methods of promotion (advertisement, sales development etc.) and stability is an important factor on the brand perception of the consumer. However, the essence of the study is to analyze the social media accounts as being one of the marketing communication tools. For this reason, it is required to explain how the social media is used by the housing brands as a means of marketing communication and how and through which methods the companies can manage their accounts and how they utilize them when introducing the brand and which message content they convey. In this research, it is aimed to show how housing brands benefit from social media in marketing communication. From the choice of 
digital platforms used to reflecting brand management philosophy on the communication channel, every application in the process gains importance. Content analysis method has been defined as a way to evaluate how the housing brands use social media as a means of marketing communication. Since there has been no other study on how housing brands use social media in managing their communication strategies, the importance of the research is prominent.

As a result, within the framework of conditions to determine research samples, it is aimed to reveal which social media platforms the housing brands in Turkey actively use and to what extent, what type of marketing communication tool is used for the content shared and classification of appropriate content to be used in each platform.

\subsection{Sampling}

The analysis of social media accounts is based on firm rankings made by official organizations that are influential in the classification of national and international housing brands in Turkey. First of all, the companies listed in "Economist' TOP 50" (2012), the most current results-in alphabetical order- of the research called "50 Housing Brands of Turkey" (2012), which is carried out by Economist Magazine for the second time and reveals the most powerful housing brands of Turkey, the member companies of the Association of Housing Developers and Investors (KONUTDER, 2016), assuming the mission of increasing competitiveness among its members based on know-how, which is a member of the Association of Real Estate and Real Estate Investment Partnership (GYODER, 2016), as the "Real Estate Platform of Turkey", which is the representative and the pioneer of the sector, and brings all the segments of the sector together under the same roof as the "Platform", and the companies, which have significant national and international position and has won an award for the completed projects in 2015 at Sign of City Awards, organized to encourage construction and real estate sector in Turkey have been taken into consideration. As a result, the firm receiving at least three positive marks in terms of membership and rankings has been included in the ranking of housing brands.

Table 2: Housing Brands Analyzed

\begin{tabular}{|l|l|l|l|l|l|}
\hline No: & $\begin{array}{l}\text { NAME OF } \\
\text { COMPANY }\end{array}$ & $\begin{array}{l}\text { ECONOMIST TOP } \\
50(2012)\end{array}$ & $\begin{array}{l}\text { GYODER } \\
\text { MEMBERSHIP } \\
(2016)\end{array}$ & $\begin{array}{l}\text { KONUTDER } \\
\text { MEMBERSHIP } \\
(2016)\end{array}$ & $\begin{array}{l}\text { SOTC } \\
\text { AWARDS } \\
2015\end{array}$ \\
\hline 1 & $\begin{array}{l}\text { Artaş İnşaat (Avrupa } \\
\text { Konutlar1) }\end{array}$ & $\mathrm{X}$ & & $\mathrm{X}$ & $\mathrm{X}$ \\
\hline 2 & Garanti Koza & $\mathrm{X}$ & $\mathrm{X}$ & $\mathrm{X}$ & \\
\hline 3 & Mesa & $\mathrm{X}$ & $\mathrm{X}$ & $\mathrm{X}$ & \\
\hline 4 & Nef & $\mathrm{X}$ & $\mathrm{X}$ & $\mathrm{X}$ & $\mathrm{X}$ \\
\hline 5 & Sinpaş & $\mathrm{X}$ & $\mathrm{X}$ & $\mathrm{X}$ & $\mathrm{X}$ \\
\hline 6 & Soyak & $\mathrm{X}$ & $\mathrm{X}$ & $\mathrm{X}$ & $\mathrm{X}$ \\
\hline 7 & Teknik Yap1 & $\mathrm{X}$ & $\mathrm{X}$ & $\mathrm{X}$ & $\mathrm{X}$ \\
\hline 8 & Torunlar GYO & $\mathrm{X}$ & $\mathrm{X}$ & $\mathrm{X}$ & $\mathrm{X}$ \\
\hline
\end{tabular}

*the firm receiving at least three positive marks has been included in the ranking of housing brands. 
In terms of social media tools, the ones that are actively used with many links and trusted are preferred. The links to the tools that branded housing companies have declared on their corporate web sites in terms of reliability are taken as basis in this study. As described in the literature section, social networks, blogs, collaborative sites, forum plan panels, and content collectors are all categorized as described in the literature.

Table 3: Ranking of Housing Brands and Social Media Tools Analyzed

\begin{tabular}{|c|c|c|c|c|c|c|c|c|c|c|c|}
\hline No & $\mid \begin{array}{l}\text { NAME OF } \\
\text { COMPANY }\end{array}$ & Google + & Facebook & Twitter & Instagram & YouTube & LinkedIn & Plaxo & Blog & Myspace & Pinterest \\
\hline 1 & $\begin{array}{l}\text { Artaş İnşaat } \\
\text { ( A v r u p a } \\
\text { Konutları) }\end{array}$ & & $\mathrm{X}$ & $X$ & & & & & & & \\
\hline 2 & $\begin{array}{l}\text { G a r a n t i } \\
\text { Koza }\end{array}$ & \multicolumn{10}{|c|}{ Since there is no application, it is not analyzed. } \\
\hline 3 & Mesa & & $X$ & $X$ & $X$ & & & & & & \\
\hline 4 & Nef & & $\mathrm{X}$ & $\mathrm{X}$ & $\mathrm{X}$ & $\mathrm{X}$ & $\mathrm{X}$ & & $\mathrm{x}$ & & \\
\hline 5 & Sinpaş & X & $X$ & X & $X$ & $X$ & $X$ & & & & \\
\hline 6 & Soyak & & $\mathrm{X}$ & $\mathrm{X}$ & $X$ & $\mathrm{X}$ & & & & & \\
\hline 7 & Teknik Yap1 & & $\mathrm{X}$ & $\mathrm{X}$ & $\mathrm{X}$ & $X$ & $X$ & & & & \\
\hline 8 & $\begin{array}{l}\text { Torun lar } \\
\text { GYO }\end{array}$ & \multicolumn{10}{|c|}{ Since there is no application, it is not analyzed. } \\
\hline
\end{tabular}

\section{*the tools actively used and specified by the companies on their corporate web sites are considered.}

\section{3. Reliability of the Research}

In terms of the reliability of the research, the content analysis must be objective, that is different observers can observe the same events on the same material. The reliability level of a content analysis depends on the function of the referees' skills, insight and experience (individual reliability) and on the reliability of the categories (category reliability) of the recording units (Y1ldırım and Simsek, 2013: 290). To this end, the two encoders in the research separately codified social media content for marketing communication methods such as personal sales, public relations, sales promotion, advertising and direct marketing. Approximately $95 \%$ of the marketing communication methods examined have formed a consensus, while in conflicting accounts, the encoders have agreed in which category the related social media content to be classified. For example, as the posts of the housing brands to introduce their projects that are directed to the sales offices are regarded as offline promotion, they are evaluated under advertisement category and in public relations category, the studies directing the sales and describing the reputation and management of the company are examined. The social media accounts, which are active in the official corporate website of the housing brands, are based on this. Thus, if relevant social media account opened by a housing brand and used actively, it is regarded as the basis for reliability. In addition, to increase the scope of the study and to measure the communication performance and posts among the followers of the page, the average 
engagement rateof each content depending on the marketing communication tools are calculated separately for each social media platform and the average engagement rates of social media platforms are calculated separately. The engagement rate formula is used for the calculation. There was no need for any auxiliary program to perform proportional calculations and to classify the contents, and necessary processing is performed in Microsoft Excel program.

\subsection{Content Classification and Categories}

The contents of social media account housing brand companies are classified according to the type and structure of marketing communication methods. As the methods of promotion (marketing communication) advertising, public relations, sales promotion, direct marketing and personal sales classification are based on and the related literature is followed (Mucuk, 2012). The variables used in the content classification and the categories used to classify each variable are described below. In addition, the description of the classification is clearly stated in the table.

Advertisement: According to the definition of American Marketing Association advertising; is an informative or persuasive message about a particular person, company, or organization that is published in areas and purchased from the mass media via payment or donation. An advertisement is a promotional activity made in any form of product, service or idea by paying the costs thereof in a non-personal way (Kotler and Armstrong, 2010: 454). Hutt and Speh pointed out that the three main objectives of the advertisement are to increase sales efficiency, raise sales efficiency and raise awareness (2001: 410411). Advertising alone is not sufficient and should be supported by other marketing communication tools. Because, depending on the nature of the housing product, how much financing the consumer has for the housing and the expectations differ. It is possible to carry out advertising campaign strategies on websites, call centers, brochures, newspaper-radio-TV, promotion boards, shopping malls, magazines and sectoral publications depending on the type of housing and the desired effect.

Public Relations: It is also a component of corporate relations activities. The task of public relations is to monitor public attitudes, uncover public problems, and develop programs in order to build a positive link between the firm and its stakeholders. The reason for the use of public relations by the companies is to be able to advertise through these activities. With public relations, the firm, employees, ideas and corporate image can be supported, and even an inner common understanding can be developed among the employees (Ferrel and Hartline, 2011: 303-304). Public relations, floor ownership sales, event organization, sponsorship (e.g. in a very popular TV program) can be effective in marketing housing.

Direct Marketing: According to the definition of Direct Marketing Association (DMA), direct marketing is a marketing system in which one or more communication media is used to get a feedback. Direct marketing is an interactive process where the valuable feedback from the customer is stored in the database to create a profile of potential customers and acquire valuable marketing information (thedma.org). Direct marketing also emerges as a way to access customers, follow-up customers and sales; make promotion on blogs and 
social media and make presentations in games or downloadable phone applications.

Personal Sales: The American Marketing Association defines personal sales as faceto-face engagement with the customer (marketingpower.com). Housing brands can create a customer database by integrating customer relationship management with sales technology and can take full control over the activities. Repetitive sales operations can be automated to save money and the sales force can be used more effectively (Ferrel and Hartline, 2011: 313).

Sales Promotion: As a marketing communication tool, sales promotion activities are carried out together with other forms of communication in a coordinated way. In addition, sales development is defined as a variety of marketing activities out of personal sales, advertising, or public relations, but assuming similar roles, such as encouraging purchasing and providing effective distribution (Jones, 2008: 178; Jorgensen, 2012). Sales development promises added value to the target audience and tries to convince the audience to buy. These persuasive efforts can target consumers, distributors, or business people (Fill, 2009: 538). In other words, it is possible to talk about developing three different types of sales promotion: consumer, intermediary and sales force. When it is considered that the housing product is a long term investment tool at a high price based on many different factors (such as environmental conditions, legal practices, price, brand value, investment or residential purpose), it is very important how and how long sales development activity will be applied by carrying such meticulously to prevent the consumers' perception about brand value, image and quality from adverse effects.

As a result, an integrated marketing communications campaign must be conducted depending on the objectives of the housing brand in the marketing communication. Because housing product contains psychological benefits, product price is generally high, customer needs detailed information, number of customers is specific and target audience shows different characteristics in a specific geographical area, sales are not regular and continuous, there are special production and design possibility for the customers, supports advertisement sales but it is remains weak to provide the individual what he wants.

It is also important to measure a social media campaign in reviewing the contents of social media accounts of housing brands, and there are a variety of metrics currently available for measuring company pages or post contents. Key metrics include web traffic statistics such as ROI, click-through, visit and number of single visitors, and proportional transactions that show the engagement between profile and followers (Zarella, 2010: 207). Instruments such as Google Analytics, Omniture, Klout, PeerIndex, ViralHeat and FeedBurner have been made available to social media account managers to measure these metrics (Özkaşıkçı, 2012: 138).

In order for the organization's social media account to be regarded as successful, the followers of the platform should be converted to potential customers through posted content. The main element of this transformation is the visitor's engagement with the social media platform.

As a result, companies use social media to communicate with their customers. In terms 
of communication possibilities, what makes social media unique is it allows for customer engagement (Akyüz, 2013: 288). In this context, it can be said that the engagement values in performance measurement are important when considering the specific characteristics of the housing market and the functions that the social media has gained in communication. The most significant indicator revealing engagement skills of social media is the engagement rate. The formula of engagement rate is as follows (socialbakers. com):

\section{Engagement rate $=$ Number of contribution to the content made by the followers $* 100$ Total number of followers (fans)}

The contribution that followers make to the content may vary depending on the platform. For example, while a contributor is meant to include followers sharing their appreciation, interpretation, and content with all kinds of activity related to the features of the Facebook application; it expresses re-tweet, favorites and comments on Twitter. A rating of between 0.5 and 0.99 indicates an average account, while a lower value indicates a bad managed social media account, yet, on the other hand a rating above 1 indicates a successful social media account. However, the total number of followers / fans of the account must also be taken into consideration when assessing the engagement performance of a business account. It is because when a social media account has a high number of followers, the content of the post may lower the engagement rate. At the same time, in a general sense, a less successful company account can capture high engagement rates because of the relatively small number of followers.

\section{RESULTS}

\subsection{Data and Findings}

Evaluation of the research consists of two parts. The first part represents the seperation of the shared content by the firms within social media platforms. In the second part, the performance of the shared content in terms of the social media platform and the type of the content by the calculation of engagement rates.

With regard to the literature, Table 4 shows the classification of the contents in terms of marketing communications (MARCOM) efforts and their sub-classifications in accordance with the purpose of the message given. Shared contents of the examined social media accounts have been content analyzed with regard to the stated classification. 
Table 4: Classification of Dimensions for Content Analysis and Engagement Rates

\begin{tabular}{|c|c|c|c|}
\hline $\begin{array}{l}\text { MARCOM } \\
\text { Dimension }\end{array}$ & & Context of the Content & Source \\
\hline \multirow[t]{10}{*}{ Advertising } & $1 \mathrm{a}$ & $\begin{array}{l}\text { Product, brand information and display, directive content } \\
\text { (Delivering pure product information, function, price, pure } \\
\text { brand introduction, slogan, logo, color, and words. }\end{array}$ & 1,2 \\
\hline & $1 \mathrm{~b}$ & $\begin{array}{l}\text { Corporate information and directing content. (Pure } \\
\text { corporate/company introduction, facilities, number of } \\
\text { employees, product range, etc...) }\end{array}$ & $\begin{array}{l}\text { Odabaş1 \& Oyman, } \\
\text { 2010: } 101\end{array}$ \\
\hline & $1 \mathrm{c}$ & $\begin{array}{l}\text { Corporal news and developments (Reqruitments, new } \\
\text { partnerships, turnover, income, capacity increases, new } \\
\text { market and industry entries, new assignments, etc...) }\end{array}$ & $\begin{array}{l}\text { Odabaş1 \& Oyman, } \\
\text { 2010: } 101\end{array}$ \\
\hline & $2 \mathrm{a}$ & $\begin{array}{l}\text { Delivery of business problems or ideals and corporate } \\
\text { identity (mission, vision)(irrelevant from the company and } \\
\text { the brand) }\end{array}$ & Yolaç, 2004: 196-197 \\
\hline & $2 b$ & $\begin{array}{l}\text { Conversation efforts irrelevant from the company or the } \\
\text { sector. }\end{array}$ & $\begin{array}{l}\text { Odabaş1 ve Oyman, } \\
\text { 2010: } 130\end{array}$ \\
\hline & $2 \mathrm{c}$ & $\begin{array}{l}\text { Expressing opinions about corporal issue and ideals and/or } \\
\text { corporal identity. }\end{array}$ & $\begin{array}{l}\text { Ferrel \& Hartline, 2011: } \\
303\end{array}$ \\
\hline & $2 d$ & $\begin{array}{l}\text { Social, environmental, economic, and sectoral news, press } \\
\text { releases, general content about the field. }\end{array}$ & $\begin{array}{l}\text { De Pelsmacker et al., } \\
\text { 2007: } 297\end{array}$ \\
\hline & $2 \mathrm{e}$ & Content about corporate social responsibility (CSR) & Yolaç, 2004: 196-197 \\
\hline & $2 f$ & Sponsorship notifications & Tek \& Özgül, 2005: 749 \\
\hline & $2 \mathrm{~g}$ & $\begin{array}{l}\text { Awards received, presentations of reports \& whitepapers, } \\
\text { sharing moments from social occasions which do not aim } \\
\text { for personal selling (training, seminars, conferences, etc...) }\end{array}$ & $\begin{array}{l}\text { Odabaş1 \& Oyman, } \\
\text { 2010: } 155\end{array}$ \\
\hline \multirow[t]{3}{*}{$\begin{array}{l}\text { Personal } \\
\text { Selling }\end{array}$} & $3 a$ & $\begin{array}{l}\text { Interrogative content with purposes of receiving feedback } \\
\text { from customers and gathering information following after- } \\
\text { sales services. }\end{array}$ & Blythe, 2006: 255 \\
\hline & $3 b$ & $\begin{array}{l}\text { Posts before and after commercial activities/events (trade } \\
\text { fairs, exhibitions, sample apartment, launching, etc...) }\end{array}$ & $\begin{array}{l}\text { Fill \& McKee, 2011: } \\
283\end{array}$ \\
\hline & $3 \mathrm{c}$ & $\begin{array}{l}\text { Content aiming for gathering marketing information } \\
\text { just as customer satisfaction, expectations (surveys, } \\
\text { questionnaires), questions, and content related to after-sales } \\
\text { services }\end{array}$ & $\begin{array}{l}\text { Odabaş1 \& Oyman, } \\
\text { 2010: } 167-168\end{array}$ \\
\hline \multirow[t]{2}{*}{$\begin{array}{l}\text { Direct } \\
\text { Marketing }\end{array}$} & $4 \mathrm{a}$ & $\begin{array}{l}\text { Contents which divert to online purchasing (Online } \\
\text { catalogue, price list, live support, web site land page for } \\
\text { purchasing, etc.) }\end{array}$ & $\begin{array}{l}\text { Fill \& McKee, 2011: } \\
281\end{array}$ \\
\hline & $4 \mathrm{~b}$ & $\begin{array}{l}\text { Content for database generation (Online forms, posts } \\
\text { designed to obtain personal data from followers) }\end{array}$ & $\begin{array}{l}\text { Pickton \& Broderick, } \\
\text { 2001: } 585\end{array}$ \\
\hline $\begin{array}{l}\text { Sales } \\
\text { Promotion }\end{array}$ & $5 \mathrm{a}$ & $\begin{array}{l}\text { Price discounts, refunds, draws, prizes, contests, campaigns, } \\
\text { etc... }\end{array}$ & $\begin{array}{l}\text { Odabaş1 \& Oyman, } \\
\text { 2010: } 203\end{array}$ \\
\hline
\end{tabular}

Source: Derived fromBatum, 2014. 
Table 5: Classification of Facebook Posts \& Engagement Rates

\begin{tabular}{lll}
\hline Dimension & \# Content & Avrg. Eng. Rate \\
\hline 1a & 270 & 0,6034 \\
$1 \mathrm{~b}$ & 54 & 0,417266 \\
$1 \mathrm{c}$ & 4 & 0,406294 \\
Advertising & $\mathbf{3 2 8}$ & $\mathbf{0 , 5 7 0 3 5 2}$ \\
$2 \mathrm{~b}$ & 313 & 1,073828 \\
$\mathrm{2c}$ & 2 & 0,470947 \\
$\mathrm{~cd}$ & 13 & 0,788448 \\
$\mathrm{de}$ & 10 & 0,207827 \\
$2 \mathrm{f}$ & 3 & 0,134461 \\
2g & 96 & 0,323538 \\
Public Relations & $\mathbf{4 3 7}$ & $\mathbf{0 , 8 7 1 4 9}$ \\
3a & 2 & 1,35414 \\
3b & 7 & 0,670867 \\
Personal Selling & $\mathbf{9}$ & $\mathbf{0 , 8 2 2 7 0 5}$ \\
Direct Selling & $\mathbf{8 7}$ & $\mathbf{1 , 1 5 0 4 8 9}$ \\
Sales Promotion & $\mathbf{4 8}$ & $\mathbf{3 , 9 7 9 7 4 4}$ \\
Total & $\mathbf{9 0 9}$ & \\
\hline
\end{tabular}

Table 5 represents the data about the MARCOM tools' performance for Facebook. The table shows that Advertising and PR related content have higher engagement rates. On the other hand, Facebook is the most active SM platform with 909 posts from 6 different SM accounts. In general, engagement rates in Facebook are above average for all main dimensions. In other words, Facebook audience engage in with the posts above average. This means that Facebook is a useful medium for the sector. On the other hand, personal selling engagement are far above average. Furthermore, direct marketing and sales promotion rates are the highest among other SM platforms.

Table 6: Classification of Twitter Posts \& Engagement Rates

\begin{tabular}{|c|c|c|}
\hline Dimension & \# Content & Avrg. Eng. Rate \\
\hline 1a & 268 & 0,092743 \\
\hline $1 \mathrm{~b}$ & 63 & 0,085472 \\
\hline $1 \mathrm{c}$ & 8 & 0,034091 \\
\hline Advertising & 339 & 0,090008 \\
\hline $2 b$ & 256 & 0,123125 \\
\hline $2 \mathrm{c}$ & 2 & 0,036795 \\
\hline $2 \mathrm{~d}$ & 36 & 0,14109 \\
\hline $2 \mathrm{e}$ & 4 & 0,073618 \\
\hline $2 \mathrm{f}$ & 3 & 0,0643 \\
\hline $2 \mathrm{~g}$ & 79 & 0,089755 \\
\hline Public Relations & 380 & 0,11645 \\
\hline $3 a$ & 15 & 0,030767 \\
\hline $3 b$ & 1 & 0 \\
\hline Personal Selling & 16 & 0,028845 \\
\hline Direct Selling & 40 & 0,030123 \\
\hline Personal Selling & 17 & 0,333061 \\
\hline Total & 792 & \\
\hline
\end{tabular}


Table 6 shows the data of Twitter posts. Engagement performance of Twitter posts level down the average engagement rates MARCOM dimensions. Despite being the second most active platform in terms of content number, the engagement rates are considerably low. Another notable point is that corporal content (1b) rates are close to product/brand content (1a) rates. In Facebook, 1a rates were one and a half times higher that $1 \mathrm{~b}$. This result indicates that characteristics of Twitter audience differ from Facebook audience in some respects.

Table 7: Classification of Instagram Posts \& Engagement Rates

\begin{tabular}{lll}
\hline Dimension & \# Content & Avrg. Eng. Rate \\
\hline 1a & 275 & 0,764393 \\
$1 \mathrm{~b}$ & 27 & 0,89682 \\
$1 \mathrm{c}$ & 1 & 1,06285 \\
Advertising & $\mathbf{3 0 3}$ & $\mathbf{0 , 7 7 7 1 7 9}$ \\
2b & 358 & 1,126399 \\
2c & 1 & 0,332336 \\
2d & 5 & 1,299042 \\
2e & 1 & 1,19407 \\
2f & 5 & 0,964105 \\
2g & 68 & 0,913148 \\
Public Relations & $\mathbf{4 3 8}$ & $\mathbf{1 , 0 9 1 7 5 1}$ \\
3a & & \\
3b & 7 & 0,932858 \\
Personal Selling & $\mathbf{7}$ & $\mathbf{0 , 9 3 2 8 5 8}$ \\
Direct Marketing & $\mathbf{4}$ & $\mathbf{0 , 8 4 1 4 8}$ \\
Sales Promotion & $\mathbf{2 4}$ & $\mathbf{0 , 6 6 8 9 4 1}$ \\
Total & $\mathbf{7 7 6}$ & \\
\hline
\end{tabular}

The table showing the Instagram data indicates that engagement of $1 \mathrm{~b}$ is higher than $1 \mathrm{a}$. However, the difference between the number of posts is more than Twitter and Facebook. In other words; despite having a higher engagement rate, number of the posts shared are less. By the way, at Public Relations (PR) dimension, type $2 \mathrm{~b}$ contents support Instagram and type $2 \mathrm{~g}$ contents have attained close rates to $2 \mathrm{~b}$. On the other hand, Instagram have the highest engagement rates among all SM platforms. Another interesting finding is that sales promotion contents have the lowest engagement rates. In other platforms there were a reverse situation. 
Table 8: Classification of LinkedIn Posts \& Engagement Rates

\begin{tabular}{lll}
\hline Dimension & \# Content & Avrg. Eng. Rate \\
\hline 1a & 27 & 0,351396 \\
1b & 7 & 0,633633 \\
1c & 4 & 0,892686 \\
Advertising & $\mathbf{3 8}$ & $\mathbf{0 , 4 6 0 3 6 5}$ \\
2b & 49 & 0,381942 \\
2c & 1 & 0,30749 \\
2d & 36 & 0,78592 \\
2e & 5 & 0,445342 \\
2f & 5 & 0,320668 \\
2g & 39 & 0,566567 \\
Public Relations & $\mathbf{1 3 5}$ & $\mathbf{0 , 5 4 2 5 3 3}$ \\
3a & & \\
3b & 3 & 0,488021 \\
Personal Selling & $\mathbf{3}$ & $\mathbf{0 , 4 8 8 0 2 1}$ \\
Direct Marketing & $\mathbf{1 3}$ & $\mathbf{0 , 4 0 4 2 3 8}$ \\
Sales Promotion & $\mathbf{2}$ & $\mathbf{0 , 8 0 4 1 6 3}$ \\
Total & $\mathbf{1 9 1}$ &
\end{tabular}

LinkedIn data in Table 8 indicates that with regard to the correlation between 1a and $1 \mathrm{~b}$, we can say that it would be better to focus on corporal advertising in this channel. Instead of product introduction, displaying content for the purpose of developing brand image would better fit for LinkedIn. LinkedIn is the only platform that type $2 \mathrm{~g}$ contents have higher engagement rates than type $2 b$ and also numbers of content are much closer to each other. Because of being a Professional social network, we had predicted to sharethe exposure of more content about events, awards, prestigious efforts, corporal information, etc... However, we come across a platform in where some aphorisms have been posted. Also, sales promotion have high engagement rates but low number of posts. Another point is that direct marketing engagement is the lowest among the dimensions for the first time. 
Table 9: General Data of the Contents Suitable for Engagement Calculation

\begin{tabular}{lll}
\hline Dimension & \# Content & Avrg. Eng. Rate \\
\hline 1a & 840 & 0,48508225 \\
$1 \mathrm{~b}$ & 151 & 0,374613576 \\
1c & 17 & 0,384205824 \\
Advertising & $\mathbf{1 0 0 8}$ & $\mathbf{0 , 4 6 6 8 3 2 5 7 8}$ \\
2b & 976 & 0,8090104 \\
2c & 6 & 0,275885 \\
2d & 90 & 0,556859722 \\
2e & 20 & 0,28967625 \\
2f & 16 & 0,43875925 \\
2g & 282 & 0,433831475 \\
Public Relations & $\mathbf{1 3 9 0}$ & $\mathbf{0 , 7 0 2 5 3 3 0 8 2}$ \\
3a & 2 & 1,35414 \\
3b & 32 & 0,410989031 \\
3c & 1 & 0 \\
Personal Selling & $\mathbf{3 5}$ & $\mathbf{0 , 4 5 3 1 4 0 8 2 9}$ \\
Direct Marketing & $\mathbf{1 4 4}$ & $\mathbf{0 , 7 6 3 3 2 2 5 2 8}$ \\
Sales Promotion & $\mathbf{9 1}$ & $\mathbf{2 , 3 5 5 5 2 3 5 6}$ \\
\hline
\end{tabular}

Table 9 represents the classification and engagement rates of the whole posts which are shared in the platforms that are suitable for engagement rate calculation (Facebook, Twitter, Instagram, LinkedIn). When we have a look at the main dimensions (advertising, PR, personal selling, direct marketing, and sales promotion) we can see that the most content have been shared in PR dimension and advertising respectively. PR and advertising posts constitute $90 \%$ of all posts. On the other hand, sales promotion dimension have the highest engagement rates which means that content about sales campaigns, draws, prizes, and other types of promotions draw interest of the followers. Besides, posts about partnership and in-corporate news (type 1c) are not shared that much (depending on the number of posts). This is because of the characteristics of the sector. Also, it is seen that firms have preferred to share about housing projects - their products (1a) instead of corporal branding (1b).

In the PR dimension, the dominant content type is $2 \mathrm{~b}$. In other words, companies have shared general posts irrelevant to the sector and company just as aphorisms, life tips, and season's greetings. This may have occured because of the difficulty of creating content about the industry of the corporation continuously. Therefore, there seems a need for outsourcing some of the SM activities from professionals for a better performance. There follow noncommercial event posts - type $2 \mathrm{~g}$ (seminar, workshpos, conferences, etc...). Type $2 \mathrm{~d}$ is the third and commonly consist of press releases (newspaper interview, tv programmes, online videos, etc...). The other three content types $(2 \mathrm{c}, 2 \mathrm{e}$, and $2 \mathrm{f})$ do not 
contain substantial data for a healthy analysis.

In personal selling dimension, the only significant content type was $3 \mathrm{~b}$ which involves in posts of commercial events. The other types were insufficient in number for analysis. As a result, we can say that target auidence are not interested in following events online from $\mathrm{SM}$, the events are limited with physical contributors, and the related posts do not mean much for the followers.

Direct marketing dimension actually consists of two sub-categories and type 4 a refers to the contents which directly leads the user to purchasing page. But the structure of the sector does not support such an activity because buying a house is an investment tool and a long-term decision. Therefore, all the postsa re type $4 \mathrm{~b}$ (filling forms for Project sales, classifying customer information, etc...). We see that engagement rates of these post are about one and a half times of advertising posts.

\subsection{Limitations}

In this study, social media accounts of branded housing companies have been content analysed under stated conditions. For determining the sample, following issues have been taken into account:

- Become a member of KONUTDER and GYODER,

- Within the top 50 Branded Housing companies ranking of The Economist Magazine,

- Having active SM accounts, therefore suitable to analyze.

It should be considered that the raw data of the findings are limited with the companies in the ranking. Besides, despite using actual data, the study is among the pioneers of the field and contains initial definitions; so further studies with bigger populations are suggested.

The main assumption of the study is that the followers engage in the content they're interested in some way or another. This menas that we assume that if a follower enjoys or gets impressed with the post after the exposure, he/she somehow gets into interaction with the company via SM. Thereto, we have to assume that all followers are exposed every single shared post.

\section{DISCUSSION AND CONCLUSION}

It is now accepted that companies regard SM as a coomunication channel for communicating with their target market regardless of the sector, customer profile, or market type. Despite adaptin to SM quickly, businesses still need to manage their content quality and timing for higher impact and better brand management. This study has examined and analyzed the the content in the SM accounts of housing companies in Turkey, classified into MARCOM dimensions and got some results thanks to the data obtained by the SM platforms used, attributes of the content, and their engagement rates. 
The findings indicate that the most powerful SM platform is Facebook. When we have a look at the numeric distribution of posts, we can say that housing companies use SM for the purpose of PR and advertising. Personal selling, direct marketing, and sales promotion follow these dimensions with order. Because the costs are minimum in SM and the existence of the audience who are interested in the company, brand, product, and the content makes SM a popular platform for advertising.

Briefly, every single SM post needs to be shared in the right platform in the right time in order to obtain the highest communicational impact within the MARCOM goal pursued. This is the best and optimum way to deliver the message in the middle and long-term to the potential receivers within the frame of company culture. For instance, housing project ads should be in Facebook, corporal ads should be in the Professional network LinkedIn, funny posts should be in Instagram, and so on. Facebook fit better to fulfill forms or information exchange because login times are longer. Campaigns and similar evetns should be announced in all platforms to boost participation. Just because Instagram is more mobile, audience may be irritated to fulfill forms, participate in campaigns, or watch advertising videos; so it would be better to perform PR activities of share funny posts in order to get higher engagement.

In house branding; lifestyles and customer profile affect the whole process from the properties of the construction to the sales dynamics. This means that the consumers are included in the product development stage and a trustworthy communication is have to be constructed. SM is the predominant and the fasted communication tool which have the ability to constitute the desired image, impact, efficiency, and sales lead with the help of proficiency for selecting the right medium, content, and timing. Thus; in the age of digital age where reputation and positioning are at the forefront, housing brands can only get ahead in the competition via SM because the sector is really dynamic and emerging. Even though every housing Project sells well today, it does not mean that it will remain the same in the future. 


\section{REFERENCES}

Akar, E. (2010).Sanal Toplulukların Bir Türü Olarak Sosyal A ğ Siteleri - Bir Pazarlama İletişimi Kanalı Olarak İşleyişi, Anadolu Üniversitesi Sosyal Bilimler Dergisi, 10 (1):107-122.

Akyüz, A. (2013). Sosyal Medya, Müşteri Etkileşimi ve Sosyal CRM. Sosyalleşen Birey: Sosyal Medya Araştırmaları 1. (Ed: A. Büyükaslan; A: M: Kırık). Konya: Çizgi Kitabevi. 285-300.

Altunışık, R., Coşkun, R., Bayraktaroğlu, S. and Yıldırım, E. (2012). Sosyal Bilimlerde Araştırma Yöntemleri, Ekim, 7. Baskı, Sakarya Kitabevi.

Anitsal, İ., Girard, T. and Anitsal, M. M. (2012). Application of Services Marketing Mix Framework: How Do Retailers Communicate Information on Their Sales Receipts?. Business Studies Journal, 4 (2): 77-90

Anjum, A., More, V. S., Ghouri, A. M. (2012). Social Media Marketing: A Paradigm Shift in Business, International Journal of Economics Business and Management Studies - IJEBMS, September, 1 (3): 96-103.

Barrell, D. andNash, M. (2005). Fundamentals of Marketing for the Real Estate Proffessional, Dearborn Real Estate Education.

Batum, T. P.(2014). B2B Pazarlama İletişiminde Sosyal Medya Kullanımı: Keşifsel Bir Çalışma, (Yayınlanmamış Yüksek Lisans Tezi),Anadolu Üniversitesi Sosyal Bilimler Enstitüsü, Temmuz.

Blythe, J. (2006). Essentials of Marketing Communications. (3.Bask1). Birleşik Krallık: Pearson Education Limited.

Bowen G. and Bowen, D. (2016).Social Media: A Strategic Decision Making Tool, Journal of Global Business and Technology, Spring, 12 (1): 48-59.

Boyd, D. M. and Ellison, N. B. (2008). Social Network Sites: Definition, History and Scholarship. Journal of Computer-Mediated Communication, 13: 210-230.

Brett D. L. and Schmitz, A. (2011). Real Estate Market Analysis, Printice Hall.

Cherunilam, F. (2008). Marketing of Industrial Goods. Mumbai: Himalaya Publishing House.

Constantinides, E. and Fountain, S. J. (2008). Web 2.0: Conceptual Foundations and Marketing Issues. Journal of Direct, Data and Digital Marketing Practice, 9:231244.

Çizmeci, F. and Ercan, T. (2015). The Effect of Digital Marketing Communication Tools in

the Creation Brand Awareness By Housing Companies,Megaron, 10 (2): 149-161.

De Pelsmacker, P., Geuens, M., Van den Bergh, J. (2007). Marketing Communications, An 
European Perspective. (3. Bask1). İngiltere: Pearson Educated Limited.

Ferrel, O. C. and Hartline, M. D. (2011). Marketing Strategy. (5. Bask1). ABD: SouthWestern Cengage Learning.

Fill, C. and Fill, K. E. (2004). Business to Business Marketing - Relationships, Systems and Communications. İngiltere: Pearson Education Limited.

Fill, C. (2009). Marketing Communications: Interactivity, Communities and Content.(5. Bask1). İngiltere: Pearson Education Limited.

Fill, C. and McKee, S. (2011). Business Marketing Face to Face: The Theory and Practice of B2B.ABD: Goodfellow Publishers Limited.

Geschwender, A. (2010).Real Estate Principles \& Practices, Eight Edition.

Gomez Vasquez L. M. and Velez, I. S. (2011). Social Media as A Strategic Tool for Corporate

Communication, Revista Internacıonal De Relaciones Públicas, 2 (I): 157-174.

Gulas, Charles S., Larsen, James E. ve Coleman, Joseph W. (2009). Brand andMessage Recall: The Effects of Situational Involvement and Brand Symbols in theMarketing of Real Estate Services.Services Marketing Quarterly. 30: 333-341.

Hutt, M. D. and Speh, T. W. (2001). Business Marketing Management: AStrategic View of Industrial and Organizational Markets. (7. Bask1).Ohio: South-Western.

İçli, G. (2010). Pazarlama İletişimi Araçlarının Türk Şarap Sektörü Açısından İncelenmesi. Marmara Üniversitesi Sosyal Bilimler Enstitüsü Hakemli Dergisi, 9 (33): 127-133.

Jones, S. K. (2008).Business-to-business Internet Marketing: Seven Proven Strategies for Increasing Profits Through Internet Direct Marketing. ABD: Maximum Press.

Jorgensen, M. (2012). Social Media Marketing Strategies: B2C vs. B2B for Facebook, Twitter and Pinterest. Kanada: One Door Press.

Keskin, S. and Tanyıldız, N. İ. (2015).Kurumsal İletişimde Sosyal Medya Kullanımı: Türkiye'deki Gsm Operatörlerinin Facebook Performansları Üzerine Bir İnceleme, E-Journal of Intermedia, Fall December.2 (2): 460 - 480.

Kotler, P. and Armstrong, G. (2010). Principles of Marketing. (13. Bask1). ABD: Pearson.

Kushwaha, G.S. and Agrawal, S. R. (2015). An Indian Customer Surrounding 7p's of Service Marketing, Journal of Retailing and Consumer Services, 22:85-95.

Marketing Türkiye Dergisi Eki, IF Marketing\& Advertising, Eylül 2012.

Masterman, G. and Wood, E. H. (2007).Innovative Marketing Communications: Strategies for the Events Industry. Oxford: Elsevier/Butterworth-Heinemann.

Mimoza, K.(2013). The Factors that Influence Customer Behaviour in Housing Market in Tirana, Journal of Marketing and Management, 4 (1): 93-106.

Mucuk, İ. (2012).Pazarlama İlkeleri, Türkmen Kitabevi, 19.Basım

Odabaşı, Y. and Oyman, M. (2010). Pazarlama İletişimi Yönetimi, (9. Bask1). İstanbul: 
Kapital Medya Hizmetleri A.Ş.

Onat, F. and Alikılıç, Ö. A. (2008). Sosyal Ağ Sitelerinin Reklam ve Halkla İlişkiler Ortamları Olarak Değerlendirilmesi, Journal of Yasar University, 3 (9): 1111-1143.

Özkaşıkçı, I. (2012). Sosyal Medya Pazarla(ma): Yeni Çağda Sosyal Medya Kullanımı ve Performans Ölçümü,İstanbul: Le Color / Levent Print City.

Peiser, R. B. and Hamilton, D. (2012). Professional Real Estate Development, ThirdEdition, Urban Land Institute.

Percy, L. (2008). Strategic Integrated Marketing Communications. Theory and Practice. Kanada: Elsevier.

Pickton, D. and Broderick, A. (2001). Integrated Marketing Communications.Essex: Pearson Education Ltd.

Reece, M. (2010).Real-time Marketing for Business Growth. ABD: Pearson Education, Inc.

Russell B., Scott, L. and Askegaard, S. (2012).Research in ConsumerBehavior, Emerald Group Publishing Limited.

Scott, D. M. (2010). The New Rules of Marketing \& PR. How to Use Social Media, Blogs, News Releases, Online Video, and Viral Marketing to Reach Buyers Directly,(2. Bask1). New Jersey: John Wiley \& Sons, Inc.

Smith, P. R. and Zook, Z. (2011). Marketing Communications - Integrating Offline and Çevrimiçi with Social Media. (5. Bask1). Büyük Britanya: Kogan Page Limited.

Tek, Ö. B. ve Özgül, E. (2005). Modern Pazarlama İlkeleri.Birleşik Matbaacılık, İzmir.

Vasquez, L. M. G. and Velez, I. S. (2011). Social Media as a Strategic Tool for Corporate Communication, Revista Internacional De Relaciones Públicas, 2 (I): 157-174.

Weber, L. (2009). Marketing to the Social Web. (2. Bask1). New Jersey: Wiley \& Sons, Inc.

Yıldırım, A. and Şimşek H. (2013). Sosyal Bilimlerde Araştırma Yöntemleri, Ekim, 9.Baskı, Seçkin Yayıncılık.

Yolaç, G. (2004). Bütünleşik Pazarlama İletişimi ve Pazarlama Halkla İlişkiler, Marmara Üniversitesi Sosyal Bilimler Enstitüsü Dergisi, 6(22):191-201.

Yuan, L. L.(2009). Real Estate Marketing, Pearson, Prentice Hall.

Zarella, D. (2010). The Social Media Marketing Book. Kanada: O’Reilly Media, Inc.

\section{Internet}

http://www.milliyet.com.tr/konut-emlak/2015, (Pricewaterhouse Coopers (PWC) ve Urban Land Institute (ULI) tarafından hazırlanan “Gayrimenkulde GelişenTrendler Avrupa 2015" raporu) (accessed on 05.05.2017)

http://www.konuthaberleri.com/sektorden-haberler (accessed on05.05.2017) 
http://emlakkulisi.com/arama.php?kelime=hedef + pazara + g\%C3\%B6re+konum (accessed on 05.2017).

http://emlakkulisi.com/guncel/swot-analizi/66168 (accessed on 25.05.2017).

http://emlakkulisi.com/kentsel-stratejiden-swot-yerine-bek-analizi/129732 (accessed on 23.05.2017).

http://www.eyeflow.com/the-5-c\%E2\%80\%99s-and-the-marketing-mix-in-the-socialmedia-era/ (accessed on18.04.2017)

http://www.reklam.com.tr/reklam-yazilari/reklam-ve-halkla-iliskiler-arasindaki-farkedir/260 (accessed on 04.03.2017)

http://www.socialbakers.com/blog/1427-engagement-rate-a-metric-you-can-count-on (accessed on 15.05.2017)

http://thedma.org/(accessed on 08.05.2017).

http://www.marketingpower.com/_layouts/Dictionary.aspx?dLetter $=P \quad$ (accessed on 01.02.2017).

\section{(Footnotes)}

1 http://www.reklam.com.tr/reklam-yazilari/reklam-ve-halkla-iliskiler-arasindakifark-nedir-/260 (Erişim Tarihi: 30.06.2016)

2 http://www.pazarlamasyon.com/pazarlama/etkili-marka-kimligi-olusturmak-icin/ (Erişim Tarihi: 30.06 .2016 ) 